$12-3-2000$

\title{
Israel's Voice Muffled Amid Hail of Stones: Distortion: Confronted with a Campaign of Violence and Propaganda, Israel Goes Unheard in the Court of World Opinion
}

Kenneth Lasson

University of Baltimore School of Law, klasson@ubalt.edu

Follow this and additional works at: http://scholarworks.law.ubalt.edu/all_fac

Part of the International Law Commons, and the Military, War, and Peace Commons

\section{Recommended Citation}

Israel's Voice Muffled Amid Hail of Stones: Distortion: Confronted with a Campaign of Violence and Propaganda, Israel Goes Unheard in the Court of World Opinion, The Baltimore Sun, December 3, 2000

This Editorial is brought to you for free and open access by the Faculty Scholarship at ScholarWorks@University of Baltimore School of Law. It has been accepted for inclusion in All Faculty Scholarship by an authorized administrator of ScholarWorks@University of Baltimore School of Law. For more information, please contact snolan@ubalt.edu. 


\section{Related Articles}

Israeli families tell of Arab terrorism

March 3, 1993

Lebanon barrage faces new questions Israelis begin

to seek...

May 13, 1996

Arab-Israeli chronology in blood

July 31, 1997

Hamas accuses Israel after militant leader dies in

Damascus..

September 27, 2004

Hamas considers a pragmatic cease-fire

June 19, 2003

\section{Find More Stories About}

Israeli

Explosives

\section{Israel's voice muffled amid hail of stones}

\section{Distortion: Confronted with a campaign of violence and propaganda, Israel goes unheard in the court of world opinion.}

December 03, 2000 | By Kenneth Lasson

"WHY," I ask my colleague, a visiting law professor from the University of Haifa and a ranking colonel in the Israel Defense Forces. "Why must Israel confront stone-throwing children with tanks and live ammunition?"

"You don't understand," replies Emanuel Gross, who is at the University of Baltimore School of Law this semester teaching courses in Constitutional Victims' Rights and Comparative Criminal Process.

"Please educate me," I say.

"It is very complicated. This is not a situation such as in Lebanon, where there is a discreet border that can be defended," he says. "Here the Army is defending Jewish settlements within the West Bank and Gaza and Israel itself. There is no way to retreat, no place to go, no way to let the rock-throwers simply have their way."

Moreover, Gross continues, the demonstrators are not just a group of children hurling pebbles.

They are organized in waves. On the front line are young Palestinians, throwing stones by the hundreds. Behind them are masked teen-agers slinging rocks, some of which are large and lethal. Behind them are those with Molotov cocktails and other explosive devices.

And behind them are those shooting pistols, rifles, and machine guns with, of course, live ammunition.

It is the rear lines that attack Israeli soldiers with explosives and bullets, he says. "And although the army uses great restraint -- more than most other countries would, even when we fire back in self-defense -- there are sometimes tragedies and the world sees children being killed. But they have been put there by their own people to mobilize the world's outrage.

"It reminds us that, during the gulf war, the Iraqis placed their Scud missile launchers next to a hospital, and when the Americans bombed the military installation, the outcry was that they were bombing a hospital. The same mentality motivates the Palestinians. The other day an ambulance came into one of our settlements in the territories, but there were no injured people inside. Instead, it was filled with explosives sent by Israeli Arabs.

"In short, our citizens and our soldiers are being threatened, and not just with stones but with live ammunition. The army does not have a slingshot corps to fight back, and there is no place to retreat. What are we to do?"

If that is the case, I ask, why hasn't Israel been able to convey a more accurate picture of that version of events?

"I don't know," responds Gross, with more than a little frustration.

"I am in the U.S. until February. A few weeks ago, I went to our embassy in Washington and offered to speak on Israel's behalf, to present the true story of what's going on, to counter the very effective job being done by the Palestinians of making it appear as if they are Davids fighting Goliath, and we are not getting the truth out. But the people at the embassy just shrugged."

I understand the Israeli shrug. It is a combination of apathy and arrogance and resignation. We have always been under siege by those around us, it says, and we will always be blamed, so it is a waste of time and effort to court world opinion.

I show Gross a letter, forwarded to me by e-mail, from an American woman who lives in Haifa with her Israeli husband:

"The past month has been one of stress, tension, and worry. We are comparatively lucky here in Haifa. It has always been a city where Arabs and Jews have gotten along. But suddenly, as a result of the violence and the call to arms by the Arabs in Gaza and the Palestinian-controlled territories, the Israeli Arabs have also been involved in violent acts, and that is a development that we never expected.

"Suddenly we have a fifth column. Arab citizens are driving just a few miles outside their villages to attack Israeli civilians on our streets and cars on our highways. Now we are viewing our Israeli Arabs with suspicion and resentment. People here have agreed upon a boycott, although we personally support those Arabs who have shown moderation.

"What I am writing about, you will not have seen or read in any reports of the violence of the past two weeks. Did you know that several days before Ariel Sharon and a group of Knesset members visited the Temple Mount, a convoy of Israeli military trucks was blown up by mines that had been put on the road shortly before they passed through, killing and injuring many of our soldiers?

"What distresses us most of all is that there is no one here who presents to the world the truth of what is going on, no one who sets straight the Palestinian propaganda and distortions."

She mentions a Knesset member who just returned from the United States, dismayed at how the American media has bought into Arab propaganda. She had asked the Israeli ambassador in Washington how it could be that no spokesman presented the Israeli position, and was told that that was the function of the consulate in New York. She contacted the 
consul himself. She found that he could hardly speak English.

$1|2|$ Next

\section{MORE:}

How to treat bone spurs

Grandson, 12, admits killing Shabazz But he says her death was not intended

'Blushing' ear is no cause for alarm

Senator's wife recounts terror, helplessness as victim of obsessed stalker

Minor's future arrives early Rookie didn't expect to make a start at third this season

Wrestler found shot dead family has lost five sons Latest tragedy apparently a suicide

Please note the green-lined linked article text has been applied commercially without any involvement from our newsroom editors, reporters or any other editorial staff. 
Home $\rightarrow$ Collections $\rightarrow$ Israeli

\section{Related Articles}

Israeli families tell of Arab terrorism

March 3, 1993

Lebanon barrage faces new questions Israelis begin

to seek...

May 13, 1996

Arab-Israeli chronology in blood

July 31, 1997

Hamas accuses Israel after militant leader dies in

Damascus...

September 27, 2004

Hamas considers a pragmatic cease-fire

June 19, 2003

\section{Find More Stories About}

Israeli

Explosives
(Page 2 of 2)

\section{Israel's voice muffled amid hail of stones}

Distortion: Confronted with a campaign of violence and propaganda, Israel goes unheard in the court of world opinion.

December 03, 2000 | By Kenneth Lasson

"Had I written this letter the day of the Sharm-el Sheik agreement," concluded the woman from Haifa, "I would have told you that a great weight was suddenly lifted from our shoulders.

"But right now, we do not expect the agreement to last. We are preparing for war. It is a dreadful prospect but a reality that we must face. At dinner last night, I was astonished when my sister-in-law said, 'The sooner we have the war, the better it will be, especially $\mathrm{CNN}$, rather than to let the violence escalate.'

"My husband and I don't share these sentiments, but they may represent the overwhelming feelings in the country right now. And that leaves us with a heavy heart. Say a prayer for us ...?"

Gross reads the letter, shakes his head, and once again says he doesn't understand why Israel cannot speak better for itself.

What he does know are the facts on the ground and in the history books, and he can tick them off in logical and chronological order

He knows that Israel became a nation at least 1,800 years before the rise of Islam, and that Jews have had a continuous presence in the land for the past 3,300 years.

He knows that Jerusalem was founded by King David and has been the Jewish capital for over three millennia, but never has it been the capital of any Arab or Muslim entity, not even when the Jordanians occupied the city.

He knows that Jerusalem is mentioned more than 700 times in Jewish Holy Scriptures but not once in the Koran

He knows that in 1948 some 630,000 Arab refugees were encouraged to leave Israel by their leaders, who promised to purge the land of Jews. Instead, they became the only refugee group in the world that has never been absorbed into their own peoples' countries.

He knows that the Arabs are represented by eight nations -- not including the Palestinians -- that initiated five wars against Israel and lost each time.

He knows that the Palestine Liberation Organization's charter still calls for the destruction of the state of Israel, which has given the Palestinians most of the West Bank land and autonomy under the Palestinian Authority.

And finally, he knows that the United Nations has passed hundreds of resolutions directed solely against Israel, but was utterly silent while, between 1948 and 1967, over 50 Jerusalem synagogues and an ancient Jewish cemetery on the Mount of Olives were destroyed and desecrated by the Arabs, who also prevented Jews from visiting their holy shrines.

In contrast, under Israeli rule, all Muslim and Christian sites have been preserved, and made accessible to people of al faiths.

Why, I ask once again, hasn't Israel been able to convey these facts to the world?

Gross, neither apathetic nor arrogant nor resigned, turns, looks me in the eye, and shrugs.

Kenneth Lasson is a professor of law at the University of Baltimore and director of its Haifa Summer Law Institute.

Prev $|1| 2$

\section{MORE:}

'Gridiron': fact-based fable about felons

Md. taxpayers finance Delaware retirements

Former professor's tumultuous life ends with suicide

The whys and fall of Connie Chung

Mucous cysts are more annoying than dangerous

Police given laser gun to trap speeders 
